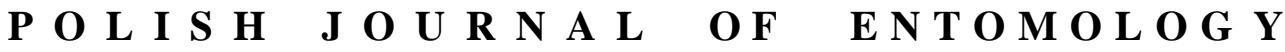

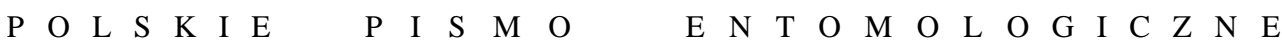

VOL. 85: 225-235

Lublin

30 June 2016

DOI: $10.1515 /$ pjen-2016-0012

\section{Tortricidae (Lepidoptera) from the Tervuren Museum, 7: The archipine genus Labidosa DIAKONOFF, 1960}

\author{
JÓZEF RAZOWSKI* \\ Institute of Systematics and Evolution of Animals, Polish Academy of Sciences, \\ Sławkowska 17, 31-016 Kraków, Poland
}

\begin{abstract}
Ten species of Labidosa are discussed; three of them (L. fontainei sp. n., L. angolana sp. n., $L$. spania sp. n.) are newly described; five species are transferred to Labidosa from other genera. New combinations: the following three species, L. cerioschema, L. cyanombra and L. myriodesma are transferred from Homona and L. symmetra from Cacoecia to Labidosa.
\end{abstract}

KEY WORDS: Lepidoptera, Tortricidae, Labidosa, Afrotropical.

\section{INTRODUCTION}

Labidosa DiAKONOFF, 1960 was described for one new Madagascan species, L. sogai DIAKONOFF, 1960 and diagnosed as "a considerably specialized off-shoot of the Homona stock”. Cacoecia ochrostoma MEYRICK, 1918 from French Congo was originally added as a probable allied species. Now, ten species are included in this genus (see the list below).

Based on the examined species one can extend the characteristics of Labidosa as follows.

Male genitalia. Uncus more or less broad; socius small, membranous; gnathos simple, rather short; valva tapering terminad, more or less triangular; brachiola broad, fairly short; sacculus broad basally, slender posteriorly; transtilla in form of labides connected by a rather weak median sclerite, with dorso-lateral spined prominences; juxta simple; aedeagus simple (or with one ventro-terminal thorn), curved; coecum penis rather short; cornuti numerous.

\footnotetext{
* Corresponding author: Razowski@isez.pan.krakow.pl
} 
Female genitalia. Cup-shaped part of sterigma well developed; antrum with variable sclerite and colliculum; ductus bursae proportionally short, coiled, with strong, proximal cestum; signum typical for Archipini, with distinct capitulum and large blade (signum absent only in the type-species).

Biology. The species were collected almost all the year round (I, II, IV, IX-XII); the altitude data of only two species (L. spania, L. cerioschema) are known: 1580 and $1700 \mathrm{~m}$ respectively.

Distribution. Apart from the type-species, all the species are continental, discovered in South Africa, Uganda, Kenya, Congo, Angola and Nigeria. Presumably, therefore, Labidosa is widely distributed throughout the Afrotropical Region.

Remarks. Labidosa is a compact genus; the species differ from one another chiefly in the colouration and male genitalia. The uncus and aedeagus exhibit the most important diagnostic characters. In females the differences are in the shapes of the cestum, signum, and to some degree in the sterigma.

\section{List of known species}

L. polyarcha (MEYRICK, 1924), South Africa, male \& female known;

L. cyanombra (MEYRICK, 1935), Belgian Congo, male \& female;

L. cerioschema (MEYRICK, 1934), Uganda, male \& female;

L. fontainei sp. n., Belgian Congo, male \& female;

L. myriosema (MEYRICK, 1936), Congo Republic, male \& female;

L. ochrostoma (MEYRICK, 1918), Central African Republic, female;

L. symmetra (MEYRICK, 1918), French Congo, female;

L. angolana sp. n., Angola, male \& female;

L. spania s. n., Kenya, male;

L. sogai DiAKONOFF, 1960, Madagascar, male \& female.

The material examined is housed in the collections of the Royal Museum for Central Africa, Tervuren (RMCA) and the Natural History Museum London (NHML).

\section{Acknowledgements}

I am grateful to Dr Jurate DEPRINS, Tervuren, for providing the material under her care for study and to Mr Kevin R. TUCK, NHML, for loaning some comparative specimens. Mr Artur CZEKAJ, Kraków, kindly photographed the specimens and arranged the plates. 


\section{SYSTEMATICS}

\section{Labidosa polyarcha (MEYRICK, 1924), comb. n.}

Homona polyarcha MEYRICK, 1924, Exotic Microlepid., 3: 106. Type-locality: Salisbury, Zimbabwe, South Africa. RAZOWSKI \& KRÜGER, 2007, SHILAP Revta Lepid., 110: 111 (holotype, female, redescription).

\section{Description}

Male genitalia (Figs 1, 2). Uncus broad, spatulate, weakly tapering basally; arm of gnathos with small subterminal prominence; valva subtriangular; brachiola broad, short; sacculus broad basally; lateral parts of transtilla with rounded, spiny lobe, median part slender, continuous; aedeagus curved; cornuti moderately long.

\section{Material examined}

One male from Bwana (II. 1929), South Africa. Coll. Transvaal Museum Pretoria (now Ditsong National Museum of Natural History).

\section{Remarks}

In male genitalia very similar to L. myriosema but the uncus in polyarcha is broader and the aedeagus shorter; female genitalia of polyarcha are similar to L. ochrostoma but with a better expressed cup-shaped part of the sterigma. In facies, this species differs from L. cyanombra and L. myriosema in having an orange forewing ground colour, dense black transverse strigulation and an orange hindwing.

\section{Labidosa cerioschema (MEYRICK, 1934), comb. n.}

(Figs 14, 15)

Homona cerioschema MEYRICK, 1934, Exotic Microlepid., 4: 526. Type locality: Kampala, Uganda. Pandemis cerioschema: BROwn 2005, World Catalogue of Insects, 5: 446.

\section{Description}

Male genitalia (Figs 3, 4): Uncus broad, somewhat narrowing basally, weakly convex apically; valva somewhat tapering terminally; sacculus convex near middle ventrally; median part of transtilla complete, lateral parts with spiny lobe; aedeagus moderately broad, simple. 

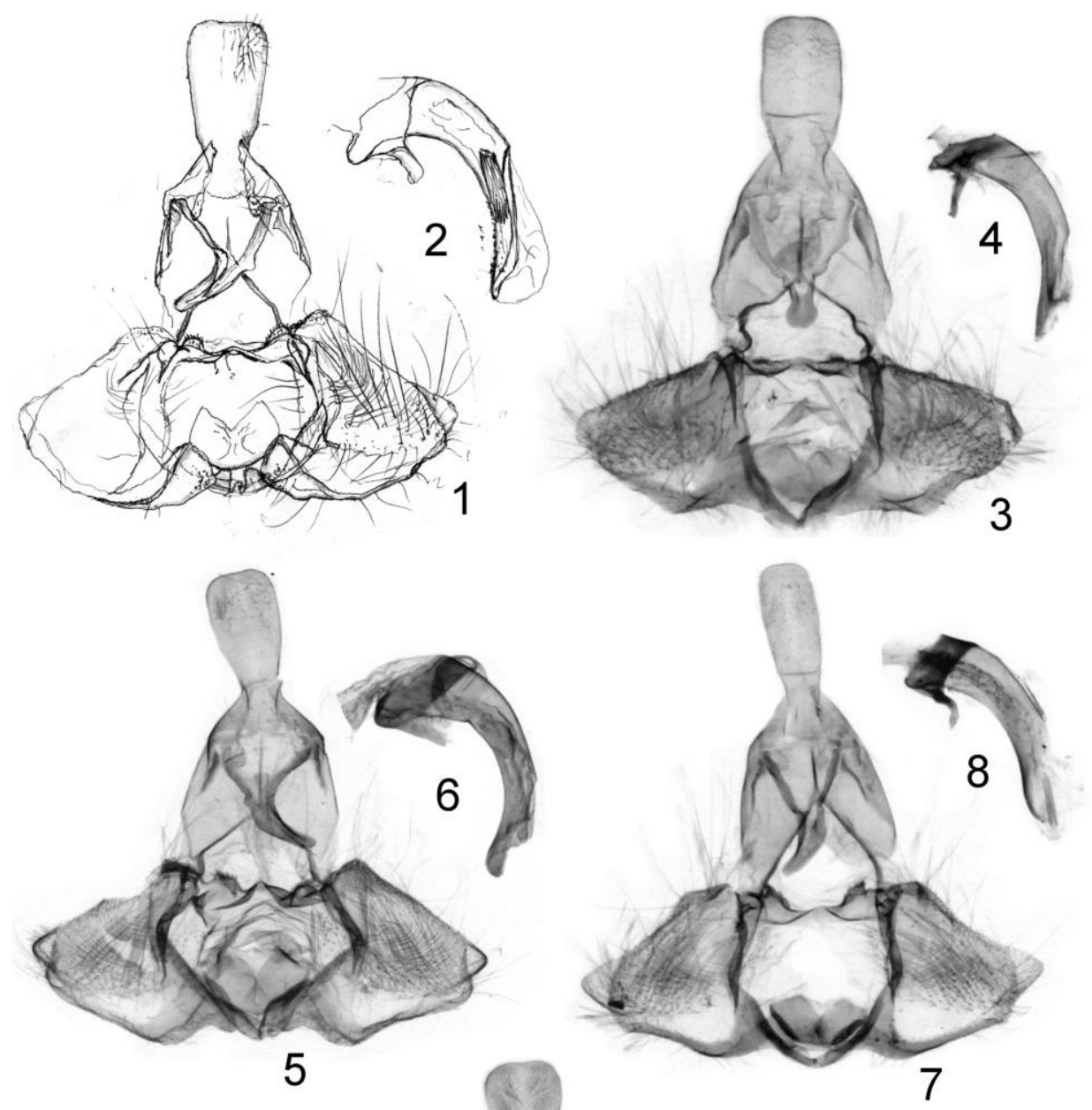

5
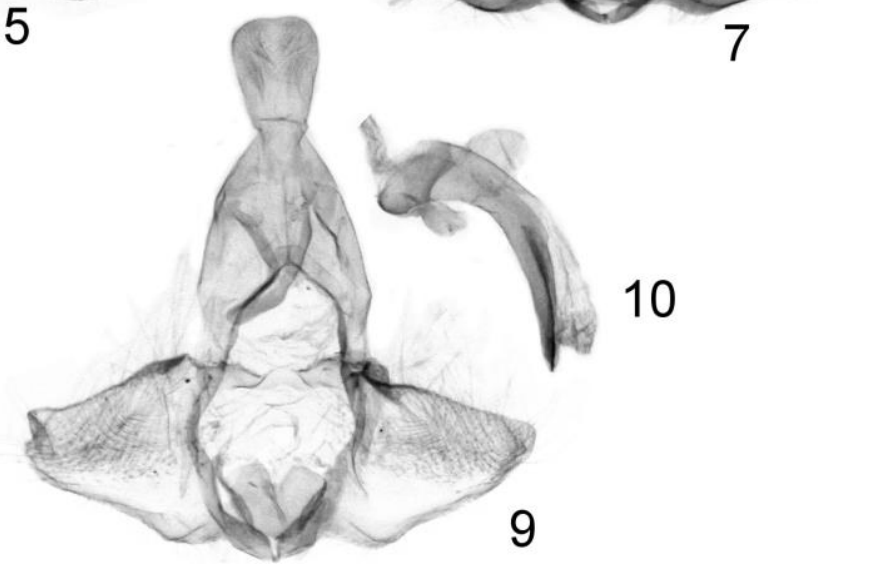

Figs 1-10. Male genitalia of Labidosa DIAKONOFF, 1960. 1, 2 - L. polyarcha (MEYRICK, 1924), RSA; 3, 4 - L. cerioschema (MEYRICK, 1934), Lusambo, Congo; 5, 6- L. fontainei sp. n., paratype; 7, 8 - L. spania sp. n., holotype; 9, 10 - L. angolana sp. n., paratype. 

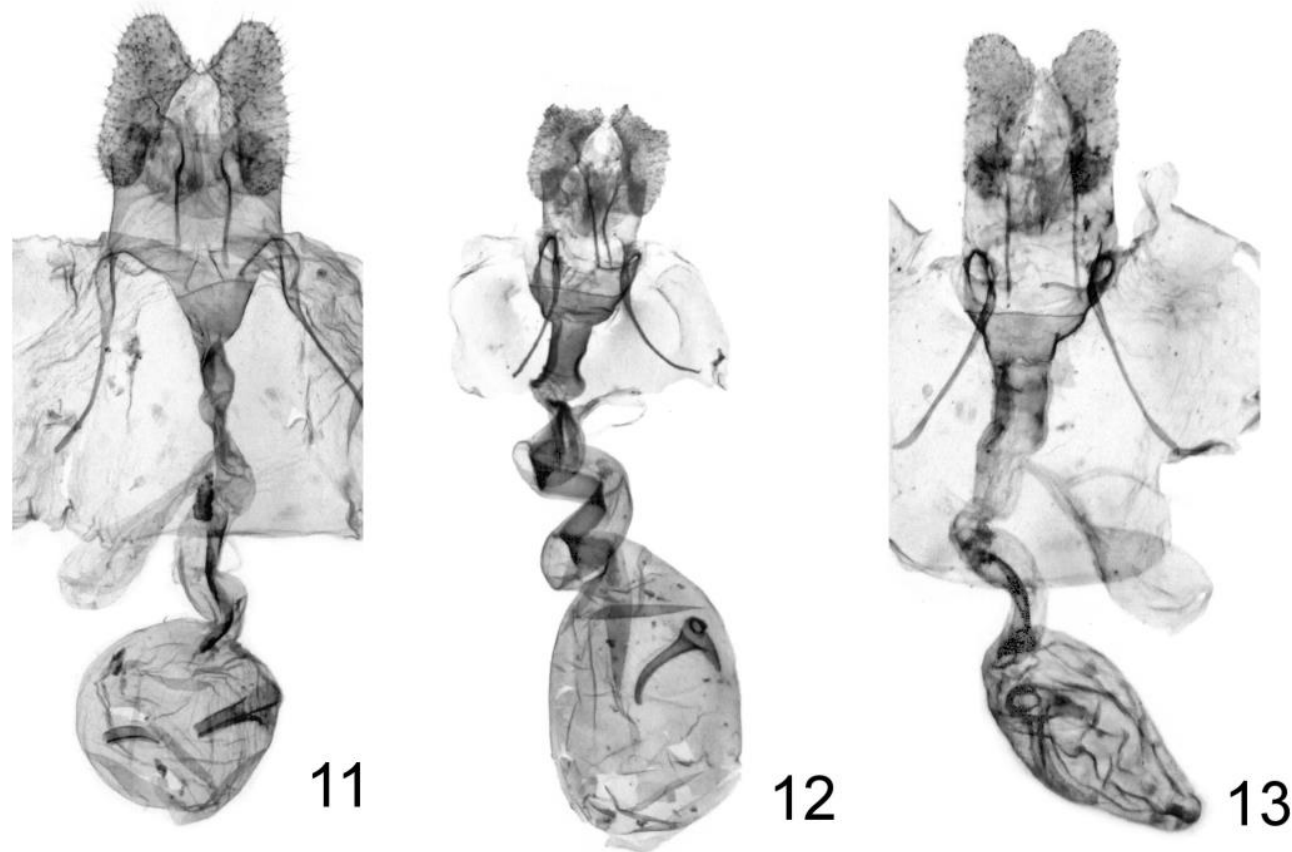

Figs. 11-13. Female genitalia of Labidosa DIAKONOFF, 1960. 11 - L. cerioschema (MEYRICK, 1934), Lusambo, Congo; 12 - L. fontainei sp. n., holotype; 13 - L. angolana sp. n., holotype.

Female genitalia (Fig. 11). Cup-shaped part of sterigma broad, tapering proximally; antrum long with ill-defined sclerite; cestum short, with two weak coils; signum blade large, capitulum small.

\section{Material examined}

Three males and 10 females from Belgian Congo (Lusambo, 7 and 21. I. 1950, 13. IV., 22. VII. 1947; Lusambo 10. VIII. 1949, 20. VIII. 1949, 22. X. 1949, 27. XII. 1949; Sankuru: Katako-Kombe, 21. XI. 1951; Uele: Paulis, 2. IV. 195, 2. IV. 1959, 9. XII. 1957 all collected by M. Fontaine; PNA, Massif Ruwenzori, Kyandolire 1700 m, Camp des Gardes, 7-15.X. 1952, P. VANSCHUYTBROECK \& J. KEKENBOSCH).

\section{Remarks}

Two not dissected syntypes in NHML. Sexual dimorphism distinct. 

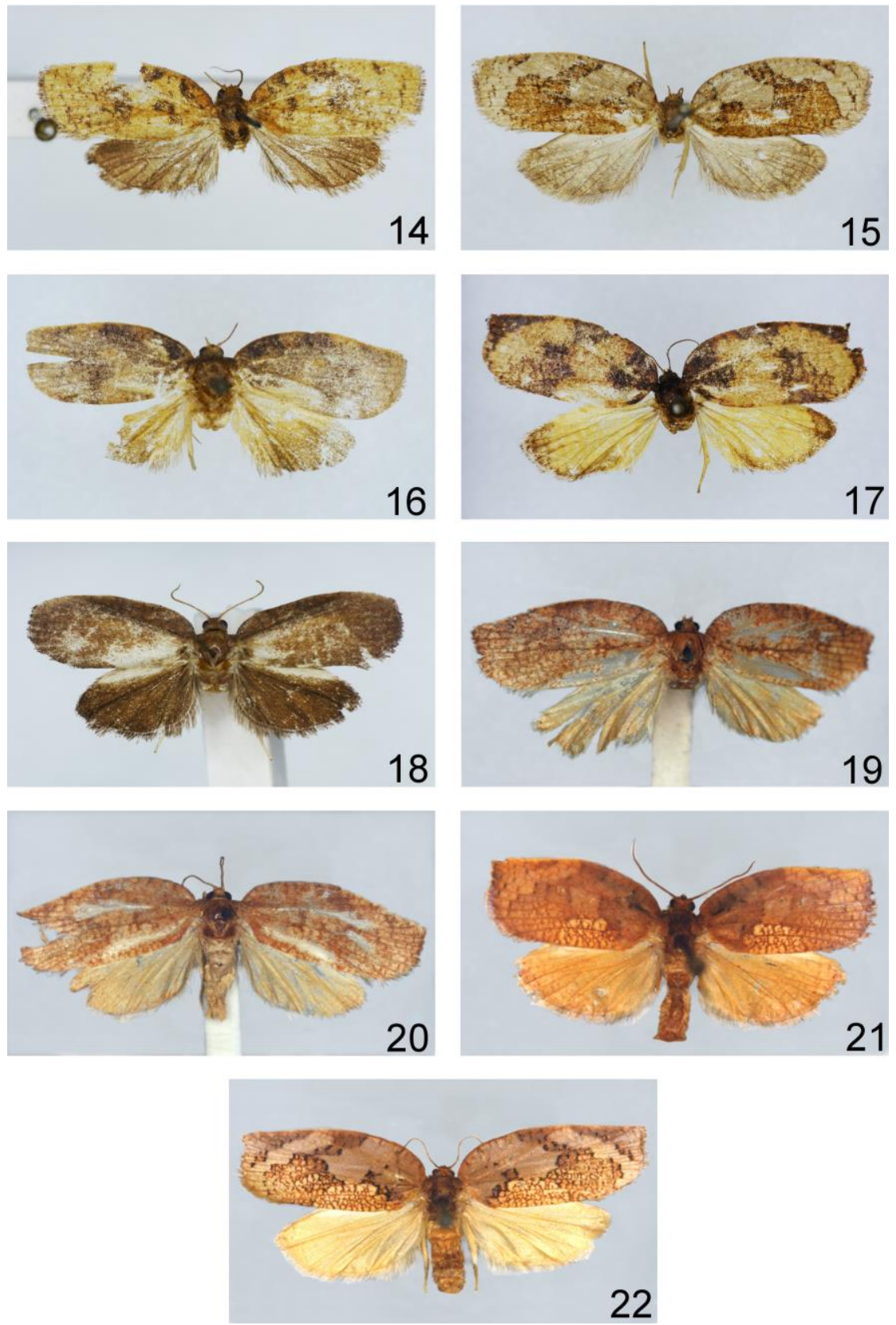

Figs 14-22. Adults of Labidosa DIAKONOFF, 1960. 14 - L. cerioschema (MEYRICK, 1934), male, Lusambo, Congo; 15 - L. cerioschema, female, Lusambo, Congo; $16-L$. fontainei $\mathrm{sp}$. n., paratype; 17 - L. fontainei sp. n., holotype; 18 - L. spania sp. n., holotype; $19-$ L. symmetra (MEYRICK, 1918), lectotype; 20 - L. symmetra, GS 31874; 21 - L. angolana sp. n., paratype; 22 - L. angolana sp. n., holotype. 
L. cerioschema is characterized by broad uncus and short cestum; it differs from L. symmetra in the brownish grey hindwing in male and the paler, reticulate female hindwing.

\section{Labidosa fontainei sp. $\mathrm{n}$.}

(Figs 16, 17)

\section{Diagnosis}

L. fontainei is related to L. cerioschema and L. ochrostoma but in fontainei the female hindwing is orange yellow edged brown and the cestum has three loops; in the male, the hindwing base is pale orange, edged brown, and the uncus is broad, narrowing basally.

\section{Description}

Wing span $32 \mathrm{~mm}$. Head and thorax blackish brown, labial palpus orange yellow, brown terminally. Forewing broadest medially; costa strongly convex; apex short; termen concave beneath apex, strongly convex at middle. Ground colour brownish yellow with slight orange hue sparsely sprinkled brown; strigulation and markings blackish brown. Basal blotch atrophying dorsally; median fascia constricted subcostally, spotted orange brownish in dorsal third; proximal edge of subapical fascia arched, posterior edge fused with apical spot. Cilia (worn) brown, orange at tornus. Hindwing orange yellow, edged brown, reticulated so at apex; cilia (remnants) paler than wing, in part brown.

Male wing span $26 \mathrm{~mm}$. Forewing costa strongly convex to middle, concave subapically; termen straight, not oblique beneath apex. Ground colour more orange brown than in female, markings brown. Hindwing orange to $1 / 3$, otherwise brown.

Male genitalia (Figs 5, 6). Uncus broad, tapering in basal third, slightly concave apically; sacculus distinctly convex at $1 / 3$; aedeagus arched, extending ventro-terminally.

Female genitalia (Fig. 12). Cup-shaped part of sterigma slenderer proximally than in posterior half; sclerite of antrum long; cestum strong, with three loops; signum delicate.

\section{Material examined}

Holotype female: "[Belgian Congo] Uele: Paulis, 19. IX. 1957, Dr. M. FonTAINE"; GS 00574. Paratype male: "Bobey IV. 1935, A. BAL”; GS 00577.

\section{Etymology}

This species is named after its collector Dr M. FonTAINE. 


\section{Labidosa spania sp. $\mathbf{n}$.}

(Fig. 18)

\section{Diagnosis}

L. spania differs from all known congeners in its brown wings; from $L$. cerioschema it differs in having a slender uncus and the curved ventro-terminal part of the aedeagus.

\section{Description}

Wing span $19 \mathrm{~mm}$. Head and thorax brown. Forewing elongate-oval; costa convex; termen distinctly convex at middle. Wing brown with paler areas and indistinct brown dots; costa slightly tinged orange. Cilia brown. Hindwing short, brown, cilia similar.

Male genitalia (Fig. 7, 8). Uncus rather slender, somewhat tapering basally; socii and gnathos typical of the genus; valva distinctly tapering terminad; sacculus convex postbasally; lobes of transtilla distinct, spined dorsally; ventro-terminal part of aedeagus weakly curved; coecum penis very short; cornuti moderately short.

Female not known.

\section{Material examined}

Holotype male: "Kenya: Kakamega F[ore]st 00 19S 034 52E, 1580 m, 17. X. 2002 leg. Ugo DALL'ASTA”; GS 00547.

\section{Etymology}

The specific epithet refers to the rarity of dark colouration in the genus; Greek; spanios not common.

\section{Labidosa ochrostoma (MEYRICK, 1918)}

Cacoecia ochrostoma MEYRICK, 1918, Exotic Microlepid., 2: 166. Type locality: Fort Crampel, French Congo = Central African Republic. Coll. NHML. Archips ochrostoma: Clarke, 1958, Cat. Microlepid. Meyrick, 3: 44 (holotype, female, illustrations). "Cacoecia" ochrostoma: DiAKONOFF, 1960, Verh. Kon. Ned. Akad. Wet., Natuurk., 53(2): 19. Labidosa ochrostoma: BROWN, 2005, World Catalogue of Insects, 5: 398.

\section{Remarks}

Apart from the holotype illustrated by CLARKE (1958) there are six specimens of which a pair is from N Nigeria (Zaria, Samara). The difference from the type cannot be assessed on the basis of the studied material. 


\section{Labidosa cyanombra (MEYRICK, 1935), comb. $\mathrm{n}$.}

Homona cyanombra MEYRICK, 1935, Exotic Microlepid., 4(19): 569. Type-locality: Kai Bumba. Lozotaenia cyanombra: RAZOWSKI \& al., 2010, Zootaxa, 2469: 13 (lectotype designated, male, redescription).

\section{Material examined}

Lectoparatype female (not dissected), with identical label data as the lectotype in the collection of NHML.

\section{Remarks}

L. cyanombra differs from L. myriosema in the brownish ground colour of the forewing, the slenderer, rounded apically uncus, and the non-serrate ventral edge of the aedeagus. The two species have a small ventro-terminal thorn on the aedeagus. The female is distinctly different from the male, especially in the shape of the forewing.

Labidosa myriosema (MEYRICK, 1936), comb. n.

Homona myriosema MEYRICK, 1936, Exotic Microlepid., 5(2): 60. Type-locality: Elisabethville, Congo (= Central African Republic). Coll. NHML. Brown, 2005, World Catalogue of Insects, 5: 388. Lozotaenia myriosema: RAZOwSKI \& al. 2010, Zootaxa 2469: 14 (holotype male, redescription, female topotype).

\section{Remarks}

In facies, L. myriosema is distinguished by its lemon yellow wings and the forewing strigulation denser than in L. cyanombra; the uncus of this species is broader than in cyanombra, concave apically; the female genitalia are as in polyarcha but the cestum in myriosema has one large loop and a very broad base.

\section{Labidosa symmetra (MEYRICK, 1918), comb. $\mathrm{n}$.}

(Fig. 19)

Cacoecia symmetra MeYRICK, 1918, Exotic Microlepid., 2: 166. Type locality: Ubangai, French Congo. Archips symmetra: ClaRKE, 1958, Cat. Microlepid. Meyrick, 3: 51 (female lectotype illustrated); BROwN, 2005, World Catalogue of Insects, 5: 130. 


\section{Remarks}

L. symmetra is distinguished by its pale orange yellow ground colour of the forewing and the much darker, more ferruginous reticulation. The markings are rudimentary. The hindwing is pale brownish orange.

\section{Labidosa angolana sp. $\mathbf{n}$.}

(Figs 20, 21)

\section{Diagnosis}

In facies, $L$. angolana is similar to $L$. cerioschema but may be distinguished by its orange yellow hindwing. The female genitalia of this species are very similar to $L$. symmetra but the blade of the signum in angolana is large and the cestum somewhat longer; besides, the two species are different externally (symmetra without any trace of grey ground colour).

\section{Description}

Wing span $29 \mathrm{~mm}$. Head pale yellowish brown, labial palpus yellower; thorax browner than head. Forewing broadest before middle; termen slightly concave beneath apex, then weakly convex. Ground colour creamish grey paler in posterior third of wing, yellowish cream in dorsal half, reticulation in the latter rust brown. Markings brownish with sparse dark brown strigulae, in dorsal area concolorous with ground colour and reticulate. Postbasal fascia preserved at the edge of yellowish ground colour; costal part of median fascia more tawny; subapical blotch tawny with proximal edge extending in form of a line to about mid-termen. Cilia pale rust brown to mid-termen, more cream otherwise. Hindwing pale orange yellow, cilia similar.

Male wing span $22.5 \mathrm{~mm}$. Forewing broad, more convex at mid-costa. Similar to female but yellowish, reticulate dorsal area smaller; remaining parts of ground colour yellowish brown with rust admixture, markings browner, indistinct.

Male genitalia (Figs 9, 10). Uncus broad, moderately short, tapering terminad; sacculus convex postbasally; lobes of transtilla weak, thorny, median part broad; aedeagus fairly long, weakly bent, tapering ventro-terminally.

Female genitalia (Fig. 13). Proximal half of cup-shaped sterigma as long as the posterior part; sclerite of antrum short, asymmetric; cestum half the length of ductus bursae, broadening proximally; blade of signum large, fairly broad.

\section{Material examined}

Holotype female: :Angola; [?] B. E. DA BELLA; slLaranjeira, E 27754, 16. 2. [19]73, TIмOTEO"; GS 31875. Paratype male with identical label data; GS 31874. 


\section{Etymology}

The specific name refers to the country of the origin.

\section{Labidosa sogai DIAKONOFF, 1960}

Labidosa sogai DiAKONOFF, 1960, Verh. Kon. Ned. Akad. Wet., Natuurk., 53(2): 18. Type locality: Ivelona Valley, Andranomalaza, East Madagascar. BROwN, 2005, World Catalogue of Insects, 5: 398 .

\section{Remarks}

L. sogai differs from all known congeners chiefly in having a slender uncus and a strongly elongate posterior part of the valva. The female genitalia do not differ from other species. Presumably, sogai is the most specialized species of the genus.

\section{REFERENCES}

Clarke J.F.G. 1958. Catalogue of the type specimens of Microlepidoptera in the British Museum (Natural History) described by Edward MEYRICK. Vol. III. British Museum (Natural History), London.

DiAKONOFF A. 1960. Tortricidae from Madagascar. Part I. Tortricinae and Chlidanotinae. Verhandelingen van Koninklijke Nederlandse Academie van Wettenshappen, Natuurkunde 53(2): 1-109, 40 pls.

Razowski J., AARVik L., Deprins J. 2010. An annotated catalogue of the types of Tortricidae (Lepidoptera) in the collection of the Royal Museum for Central Africa (Tervuren, Belgium) with descriptions of new genera and new species. Zootaxa 2469: 1-77.

Received: 22 October 2015

Accepted: 10 November 2015 